\title{
Reconstruction of Andragogical Principles in Porang Farming Community
}

\author{
Rofik Jalal Rosyanafi, Universitas Narotama, Indonesia, rofik.jalal.rosyanafi@narotama.ac.id \\ Djoko Saryono, Universitas Negeri Malang, Indonesia, djoko.saryono.fs@um.ac.id \\ Abdul Latief Bustami, Universitas Negeri Malang, Indonesia, abd.latif.fis@um.ac.id \\ Hardika, Universitas Negeri Malang, Indonesia, hardika.fip@um.ac.id
}

\begin{abstract}
This study aims to reconstruct the principles of andragogy from the perspective of the porang farmer community as a new agricultural commodity for farmer groups. Grounded Theory is a type of research with a qualitative approach that is used with a focus on obtaining an abstract analytical scheme from the learning process of porang farmer groups as adult learners. The subjects in this study were a group of porang farmers in Bulu Village, Pilang Kenceng District, Madiun Regency - Indonesia. Data collection techniques used in this study include observation, interviews, documentation and literature study of previous research. The results of this study indicate; adult learners have a learning orientation that is relevant to the problem, have a more mature and diverse concept and readiness for learning, have knowledge and experience as teaching and learning capital, have internal motivation and need external motivation, need respect and appreciation in learning, need a representative learning situation , safe and comfortable. Adult learners will also be more effective and optimal in their learning if there is certainty of learning outcomes.
\end{abstract}

Keywords: Andragogy, Prinsip Andragogy, Porang Farmer.

Received: 06.12.2020 Accepted: 10.01.2021 $\quad$ Published: 03.02.2021

\section{INTRODUCTION}

The existence of porang farmers in Madiun Regency continues to increase as Madiun Regency is designated as the center for Indonesian porang cultivation by the government through the Research and Development Agency of the Ministry of Agriculture of the Republic of Indonesia. Porang (Amorphophallus muelleri Blume), is a local perennial plant that grows in many Indonesian forests. Porang is rich in glucomannan which offers many benefits both as a food ingredient and functional food (Harmayani, Aprilia \& Marsono, 2014). LKJ (Performance Report) Department of Agriculture and Fisheries Kabupaten Madiun 2019 year, released evidence of an increase in the number of porang farmers through reports on the realization of porang production in 2019 amounting to 9,060.15 tonnes, an increase of 310.2 tonnes compared to production in 2018 or reaching $102.04 \%$ of the target of 8,879.05 tonnes. In addition, the increase in the number of porang farmers in Madiun Regency can also be seen from the area of porang plants from 1,568 ha in 2018 to 1,602 ha in 2019. As for several areas of the porang-producing farmers, in Madiun Regency covering the district. Dolopo, Kec. Dagang, Kec. Wungu, Kec. Kare, Kec. Gemarang, Kec. Madiun, Kec. Wonoasri, Kec. Pilangkenceng and Kec. Saradan. Based on these data, we can see that porang as an agricultural commodity has recently increased interest by farmers in Madiun Regency, East Java Province - Indonesia.

The renewable use of porang as an export commodity makes the transformation process of farmers from traditional local agriculture and plantations such as sugar cane, cocoa and cloves to export commodity farmers such as porang ideally becomes even faster. Currently Porang commodity is the 3rd highest export commodity in East Java Province with destination countries, Japan, China, Taiwan, England, Korea, the Netherlands, and other European countries. (Puspitorini, 2019). The phenomenon of transformation carried out by farmers is a process that is not easy, of course. This condition is because the farmers generally have maturity and strong principles in cultivating an agricultural field which they consider new. A farmer from the perspective of the diffusion innovation theory can be divided into several groups. Berdasarkan kecepatan mengadopsi inovasi, Rogers (1983), dividing farmers into five groups; inovator, early adopter, early majority, late majority, dan laggard. The five groups of farmers each have the following characteristics:

a. Innovators, have characteristics; actively looking for innovation, willing to take risks, well educated, relatively young, relatively high social mobility, having above average income, as a beginner pioneer in innovation adoption. 
b. Early adopter, have characteristics; are opinion leaders, have the courage to take risks, are well educated, are relatively young, have high social mobility, have above average income, like to try / practice new innovations introduced, are a reformer group.

c. Early majority, have characteristics; have a sense of caution in making decisions, less social mobility, average education, relatively young age, will adopt after seeing evidence from others.

d. Late Majority, have characteristics; being skeptical of innovation, relatively older age, relatively low social status, low social mobility, if adoption is more due to feelings of shame / reluctance, not because of a positive assessment of innovation.

e. Laggard, have characteristics; locally oriented, dogmatic thinking, past oriented, it takes a long time to convince them to adopt the innovation, or even will reject forever. ( Akhmad Musyafak, 2005).

Farmers in the Madiun Regency area, as far as the researcher observes in-depth, with a duration of one year, generally shows symptoms in the form of a skeptical attitude towards everything they consider new. This condition is supported by the relatively old age of the farmers over 40 years with a social status that they feel is low in relation to their profession as traditional farmers with local commodities. Porang is an export agricultural commodity that tends to be new to local farming communities in Madiun Regency.. However, these commodities actually contribute to the transformation of the farming community even though it is not significant due to the behavior and mindset of the farming community which tends to lead to the Late Majority. An interesting phenomenon in the context of the learning process (Transformative Learning), which allows them to improve their economic conditions as farmers with export commodities from before as traditional farmers with local commodities.

The learning principles of farmers as adults who are used to learn to cultivate porang as a new farm for cultivation, of course, play an important role in the successful transformation of these farmers. This reality is certainly in line with Knowles' opinion; Individuals take the initiative, with or without the help of others, in diagnosing their learning needs, formulating learning goals, identifying human and material resources for learning, choosing and implementing appropriate learning strategies, and evaluating learning outcomes. (Knowles, 1975, p. 18). Andragogy as an adult learning approach along with its principles based on Kowles' opinion, is certainly different from the practice of andragogy in general. Andragogy, in observing the practical dimension, tends to be implemented in sectors of society or adult learners with the Early adopter and Early Majority categories when viewed from an innovation diffusion perspective, such as seminars, workshops, training and courses.

From the inception of adult education, many definitions of andragogy have been offered from a number of perspectives. This has resulted in practical difficulty with teaching strategies, programplanning, curriculum design, program assessment, etc. These difficulties have hampered the development of andragogy (Gail D, 2013). There has not been a consensus on a working definition of andragogy. Moreover, adult education serves a segment of society which has a variety of needs and interests. Consequently, adult education has been criticized as unstructured and having multiple purposes (Suanmali, 1981). Researchers in this study are trying to determine and reconstruct the principles of andragogy from the perspective of farmers who are members of the Porang farmer group farmers in Bulu Village, Pilang Kenceng District, Madiun Regency, East Java Province - Indonesia who have succeeded in becoming export commodity farmers such as porang, from previously being local commodity farmers.

\section{LITERATURE REVIEW}

\section{Farmers from the perspective of the Innovation Diffusion Theory}

Farming communities in the context of this study are a group of people who work as farmers in an agricultural area. A farmer(also called an agriculturer) is a person engaged in agriculture, raising living organisms for food or raw materials. The term usually applies to people who do some combination of raising field crops, orchards, vineyards, poultry, or other livestock. A farmer might own the farmed land or might work as a laborer on land owned by others, but in advanced economies, a farmer is usually a farm owner, while employees of the farm are known as farm workers, or farmhands. However, in the not so distant past, a farmer was a person who promotes or improves the growth of (a plant, crop, etc.) by labor and attention, land or crops or raises animals (Dyer, 2007). Externally, definition on farmers by the American Everett M. Rogers is most representative. In "Rural Social Changes", he thought that, "farmers are producers of agricultural products and traditional countrymen, who tend to be relatively modest, and most of who are autarkic (although not in complete need). That is to say, most of foodstuff and other things they produce are consumed by themselves. Therefore, farmers are autarkic agricultural producers." This also means that, in traditional agricultural background, identity of farmers is positioned as "agricultural producers" (Zuohua Yue, 2009). Based on the explanations of experts, we can understand 
that a porang farmer is a farmer who is engaged in cultivating the porang plant, with the hope of selling it as an export-selling agricultural commodity.

Amorphophallus muelleri Blume, locally called porang or iles kuning, is one of glucomannan potential source in Indonesia due to its high level of glucomannan content. The tubers are not consumed and unpalatable as they contain high levels of calcium oxalate. As highly demanded export commodity, the tubers are sliced, dried to chips, milled to flour and exported without further processed into glucomannan, despite its wide application, due to the complicated long process. Glucomannan has diverse function in food, pharmaceutical (Alonso-Sande, Teijeiro-Osorio, Remuñán-López, \& Alonso, 2009; Tester \& AlGhazzewi, 2013; C. Zhang, Chen, \& Yang, 2014), cosmetics and chemical industries (Zhang, Xie, \& Gan, 2005). Porang was originally a wild plant that grew in the bush and riverbanks. Farmers who from generation to generation also do not see it as a plant that has extraordinary economic potential. Farmers from generation to generation have a mindset that is they are not brave enough to take risks and tend to cultivate crops that are easy to sell and can be consumed if unsold, such as rice, corn, soybeans, secondary crops and the like.

Farmers from the perspective of the diffusion theory of innovation have an important role, namely as a determinant of the success of an adoption of innovation or novelty (adopter), in this case porang as a new agricultural cultivation. Diffusion is the process by which an innovation is communicated through certain channels over time among the members of a social system (Rogers, 1983:5). The innovation diffusion theory has several components to support its implementation, namely:

1. The innovation, and especially potential adopter perceptions of its attributes of relative advantage (effectiveness and cost efficiency relative to alternatives), complexity (how simple the innovation is to understand), compatibility (the fit of the innovation to established ways of accomplishing the same goal), observability (the extent to which outcomes can be seen), and trialability (the extent to which the adopter must commit to full adoption);

2. The adopter, especially each adopter's degree of innovativeness (earliness relative to others in adopting the innovation);

3. The social system, especially in terms of the structure of the system, its local informal opinion leaders, and potential adopter perception of social pressure to adopt;

4. The individual adoption-process, a stage-ordered model of awareness, persuasion, decision, implementation, and continuation;

5. The diffusion system, especially an external change agency and its paid change agents who, if well trained, correctly seek out and intervene with the client system's opinion leaders, paraprofessional aides, and innovation champions (James W. Dearing, 2009).

Farming communities as adopters have a category as applicable in the diffusion theory of innovation. Rogers (2003), argued that adopters can be categorized into five groups (membership percentage in parentheses); innovators $(2.5 \%)$, early adopters $(13.5 \%)$, early majority (34\%), late majority (34\%), and laggards (16\%).

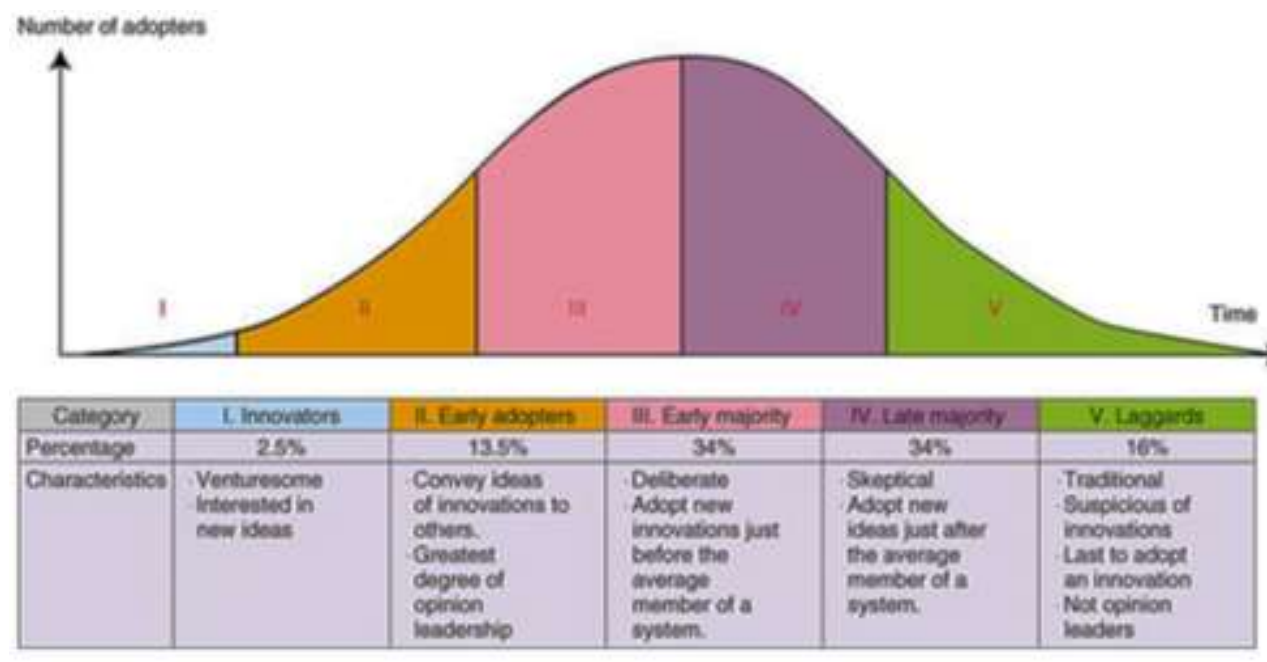

Figure 1. Innovativeness and adopter categories (Rogers, 2003)

The five categories above, with the characteristics and the number of percentages in each category of adopters, in principle, can be implemented in various fields of social systems. Farming society as a social system has categories relevant to the diffusion theory of innovation, namely; 


\section{Innovators}

Farmers' groups who are actively seeking information about new ideas in this case related to porang cultivation (Input, Process, Output). They have a high level of exposure to the mass/social media and have a wide network outside the local system that generally farmers access.

\section{Early adopters}

This farmer group is always active as early adopters. They mingle more with other members of the social system than farmers with typical innovators. Farmers in this category have a role as opinion leaders in the system. This means that the farmers of this group have an open attitude and then compete to adopt porang as a new agricultural commodity.

\section{Early majority}

This farmer group cultivates porang before the average system member / other farmer adopts it. They have strong interactions in their environment, but rarely play a role as opinion leaders. They are in a unique position, namely being between the first-time porang cultivators and the final porang cultivators when most of the farmer groups have cultivated them so that they become a bridge for both of them in the diffusion process.

\section{Late majority}

This late adopter farmer group cultivates porang after on average other group members adopt/cultivate it. This is usually due to economic considerations or pressure from the environment. They view porang as a new agricultural commodity with more skepticism and caution so that they will cultivate/adopt it only after most of the other farmer groups have done it and succeeded.

\section{Laggards}

This farmer group is the last to adopt or cultivate porang. This condition is usually caused by their way of thinking that is still oriented to the past and has few sources of information so that they must ensure that before they adopt it, the idea of porang as a new plant to be cultivated will not fail.

\section{The implementation of Andragogy Principles by farmers as adult learners}

The learning process in the farmer transformation phenomenon has a very important role, intentionally or not and whether we realize it or not. The term learning, by contrast, emphasizes the person in whom the change occurs or is expected to occur. Learning is the act or process by which behavioral change, knowledge, skills, and attitudes are acquired (Boyd, Apps, et al., pp. 100-101). Farmers as adult learners experience an andragogical process or adult learning before they finally move on as porang farmers from previously being traditional farmers with local commodities. Participatory approaches to agricultural extension recognise and value andragogy and are embraced as a solution for improved extension (McEntee, 2013).

The term andragogy was first used in 1833 by German high school teacher Alexander Kapp in a book entitled 'Platons Erziehungslehre' (Platos Educational Ideas) where, although he does not define andragogy, Kapp justifies it as the practical necessity of the education of adults (Reischmann 2004). It later became very popular in the US by the American educator Malcolm Knowles through his book entitled "Informal adult education: a guide for administrators, leaders, and teachers" in 1950. Malcolm Knowles defines Andragogy is the art and science of helping adults learn (Knowles, 1980, p. 43). 


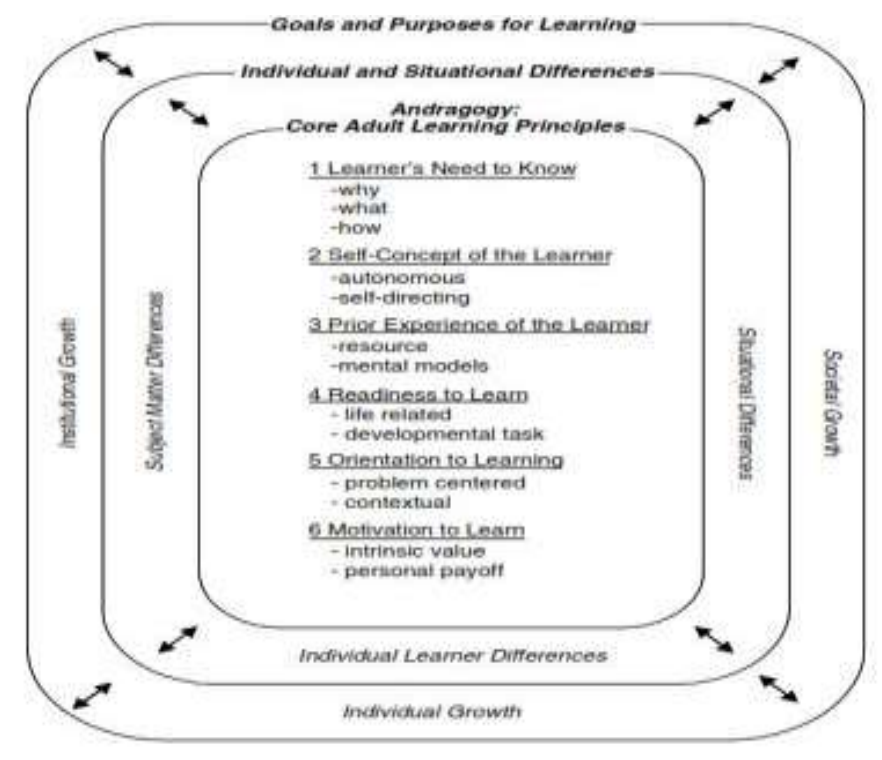

Figure 2. Andragogy in practice

(Knowles, Holton, and Swanson, 1998)

Based on the picture above, it can be seen that the implementation of andragogy is basically formed from a set of learning principles. Learner's need to know, self-concept of the learner, prior experience of the learner, readiness to learn, orientation to learning, motivation to learn, are the principles that need to be considered in the implementation of adult-based learning. The implementation of andragogy is also influenced by Goals and Purposes for Learning, Individual and Situational Differences. In the learning practice of farmers with local commodities to farmers with export commodities such as porang, of course, they have different learning principles. This may be caused by several things including learning goals and objectives, individual and situational differences.

\section{METHODOLOGY}

\section{Research design}

This research is a qualitative research method, with grounded theory (GT) design. Glaser \& Strauss (1967), defines Grounded Theory (GT) allows developing substantive theories to explain social phenomena through people interactions. The interaction process of farmers as adult learners with learning resources on porang cultivation is the main consideration in gorunded theory research as a research design. With this interaction process, it is hoped that the principles of andragogy will be reconstructed in accordance with what happened to porang farmers.

\section{Participants}

The subjects in this study were a group of porang farmers in Bulu Village, Pilang Kenceng District, Madiun Regency, East Java Province - Indonesia. The selection of groups in the area was determined using a purposive sampling technique. The porang farmer group in Bulu village is a new porang farmer group, meaning that the transformation process from traditional local community farmers to farmers with export commodities such as porang has just begun. This of course has an impact on the originality of the implementation of the principles of andragogy which is more natural. This condition is different from the farmer groups in other areas that were transformed earlier and were more successful. In determining the subject, the researcher agreed with the submission of Starks and Trinidad (2007), who stated that in qualitative researches, big sample is not a compulsion to produce the required data, because one can gather much description and idea. 
Table 1. Demographics of research subjects

\begin{tabular}{|l|l|l|l|l|l|}
\hline $\begin{array}{l}\text { Member } \\
\text { Number }\end{array}$ & Name & Age & Gender & Last Education & Porang Area \\
\hline 001 & Suwito & 54 & Male & ES & 1,5 \\
\hline 002 & Endro & 47 & Male & JHS & 2,5 \\
\hline 003 & Sukadi & 43 & Male & JHS & 1 \\
\hline 004 & Sumarno & 54 & Male & ES & 2 \\
\hline 005 & Kasdu & 42 & Male & JHS & 1 \\
\hline 006 & Joko & 40 & Male & HS & 0,5 \\
\hline 007 & Kholiq & 59 & Male & ES & 2 \\
\hline 008 & Suparman & 45 & Male & JHS & 3 \\
\hline 009 & Bambang & 39 & Male & HS & 0,5 \\
\hline 010 & Suparno & 56 & Male & ES & 1,5 \\
\hline 011 & Takim & 58 & Male & ES & 2 \\
\hline 012 & Andika & 48 & Male & JHS & 2,5 \\
\hline 013 & Sabar & 50 & Male & ES & 1 \\
\hline 014 & Adi & 52 & Male & ES & 1,5 \\
\hline
\end{tabular}

Noted: Elementary/Primary school (ES), Junior High School (JHS), High school (HS), Higher education (HE).

\section{Data Collection}

The process of gathering data and coding data is described as a zigzag, where one goes to the field gather data, goes to the office to analyze, and then back and forth. One way to compile all this information is with a conditional matrix which informs the researcher of the connections between the conditions influencing the phenomenon. (Creswell, 2013). Data collection techniques in the context of this research include ;, interviews and documentation. Observations were carried out to systematically describe the events, behaviors and artifacts of the social order that existed in the learning phenoma of the porang farmer group. The interview in this study was an interaction between researchers and members of the porang farmer group as adult learners. The researcher as an interviewer has a general plan of investigation but not a specific series of questions that must be asked in certain words and in a certain order. This procedure is taken in order to get a broad and deep picture of the principles used by the porang farmer group members in the learning process. The last data collection technique is documentation, through this technique it is hoped that data in the form of learning instrument documents, pictures and process videos so that learning outcomes can be collected as reinforcing data.

\section{Data Analysis}

In this approach, the data analysis system is divided into three stages: open coding, axial coding and selective coding. Open coding is the first analytical step, in which the researcher must focus on the collected data, examining it, comparing it and conceptualizing it with words that convey action. This step happens by analyzing each word line-by-line, meaning that a thorough examination through exhaustive questioning by the researcher regarding the data is necessary: "What is this? What does it represent? What is happening here?" Thus, identification of substantive codes, their properties and dimensions can proceed (Strauss and Corbin, 2015). In this research, Open coding stages is carried out through; Phenomenon labeling, discovery and naming of categories, compilation of categories which then break down the constituent elements of the learning principles of members of the porang farmer group.

The second step of the analysis is Axial coding, and it is marked by inductive-deductive motion, which demands theoretical sensitivity and reflection by the researcher, who seeks answers to questions such as: Why? In which way? Where? When? and How? At that time, the data that was separated in the open encoding is regrouped in order to form explanations about the researched phenomena and to enable category emergence. At this stage it can also be interpreted as the stage where the researcher combines the data in a new way after open coding (Strauss and Corbin, 2008). In the context of this study, the data that had been collected by the previous stages (Open Coding) were then entered and processed based on the central phenomenon, casual conditions, intervening conditions dan consequences of the adult learning process that occurred in the porang farmer group.

In the selective coding, the last moment of the analytical process corresponds to a refinement of the previously found categories and subcategories, continuously compared and analyzed by integrating the data and thus enabling the researcher to identify the central category or phenomenon (Strauss and 
Corbin, 2008). In the final stages of this analysis, the researcher processes by selecting core categories, systematically relating it to other categories, validating those relationships, and filling in categories that need futher refinement and development from the practices and learning principles of farmers as adult learners.

In all stages of grounded theory analysis, researchers also use memos to optimize data acquisition from the analysis. In the context of constant comparative analysis, the preparation of memos is another feature that prevails, regardless of the methodological perspective of grounded theory (Kenny and Fourie, 2015). In the practice of data analysis in this study, memos are important notes made by researchers to elaborate ideas related to data and coded categories. In other words, a memo is a note that the researcher makes for himself in order to formulate a hypothesis about a category, about the relationships between the categories found.

\section{DISCUSSION}

The display of the results was explained in three sub-topics. The topics of the findings are the result of data collection and analysis using an operational grounded theory design. The implementation of learning activities by farmers in the Porang farmer group in Bulu Village, Pilang Kenceng District, Madiun Regency, East Java Province - Indonesia, is an operational background in an effort to collect and analyze findings, which are mainly the principles of andragogy used by farmers as adult learners.

\section{General description of the porang farmer group}

The porang farmer group is a group of farmers who own porang agricultural land. Farmers in the porang farmer group were originally farmers with local commodity cultivation such as rice, corn, sugar cane, cacao, cloves, secondary crops and the like. The understanding of the vision and mission of the future of agriculture is the main reason they formed the Porang farmer group. The list of farmers from the members of the Porang farmer group is 14 farmers which include;

Tabel 2. Member of the Porang Farmer Group

\begin{tabular}{|l|l|l|l|l|l|}
\hline $\begin{array}{l}\text { Member } \\
\text { Number }\end{array}$ & Name & Age & Gender & $\begin{array}{l}\text { Last } \\
\text { Education }\end{array}$ & $\begin{array}{l}\text { Porang } \\
\text { Area (Ha) }\end{array}$ \\
\hline 001 & Suwito & 54 & Male & ES & 1,5 \\
\hline 002 & Endro & 47 & Male & JHS & 2,5 \\
\hline 003 & Sukadi & 43 & Male & JHS & 1 \\
\hline 004 & Sumarno & 54 & Male & ES & 2 \\
\hline 005 & Kasdu & 42 & Male & JHS & 1 \\
\hline 006 & Joko & 40 & Male & HS & 0,5 \\
\hline 007 & Kholiq & 59 & Male & ES & 2 \\
\hline 008 & Suparman & 45 & Male & JHS & 3 \\
\hline 009 & Bambang & 49 & Male & HS & 0,5 \\
\hline 010 & Suparno & 56 & Male & ES & 1,5 \\
\hline 011 & Takim & 58 & Male & ES & 2 \\
\hline 012 & Andika & 48 & Male & JHS & 2,5 \\
\hline 013 & Sabar & 50 & Male & ES & 1 \\
\hline 014 & Adi & 52 & Male & ES & 1,5 \\
\hline
\end{tabular}

Noted: Elementary/Primary school (ES), Junior High School (JHS), High school (HS), Higher education (HE).

Based on the data above, the members of the porang farmer group consist of prospective porang farmers over 40 years of age (Adult). All of the male farmers with the latest education are Elementary/Primary school (ES) and Junior High School (JHS) graduates. The members of the porang farmer group have a total area of 22.5 hectares with each member averaging over 1 hectare. The land they have planted or intend to plant porang is all under lease status, considering that the entire land belongs to PERHUTANI (State-Owned Enterprises of Indonesia) which is intended for the surrounding community through the Forest Village Community Institution (LMDH). Some of the land has been successfully planted by porang as a pilot group, but most of the group members are still at the stage of preparing the land.

Mr. Purwoto, as the group leader, is also the first farmer to plant porang compared to other members of the porang farmer group. The success of planting porang by Mr. Purwoto is a blessing and an 
example for members of farmer groups to learn and discuss. The existence of pilot porang that has been successfully planted by fellow farmer group members is expected to provide learning motivation for farmer group members related to porang cultivation. Apart from Suwito, there are several other members who have planted various crops. However, most have not yet reached the harvest and sale stages. However, with the existence of several porang lands that have been successfully planted, the learning activities of other farmer group members can use it as a real learning space. Suwito's decision to plant immediately, because he has the principle that his experience is learning by doing.

Another condition, which causes other members not to immediately carry out the planting, tends not to be due to the lack of courage in the substance of the plant, but is influenced by several things. The main thing is the existence of seeds that are increasingly rare and expensive. The market price of porang seeds at the beginning of the year is around Rp. 80,000, - / Kg, and currently (mid-year / before planting season) the price has jumped to Rp. 350,000, - / Kg. This condition is very reasonable due to the potential high selling price (One seed for one tree, with an estimated tree weight of 6-7 Kg). The selling price of porang after harvest per kilo is Rp. 13,000 - Rp. 15,000, -, meaning that if each tree is 6-7 kg, it can be ascertained that the gross profit earned by the farmers is Rp. 80,000 - 90,000, -. The land area of one hectare if planted with a pattern of 0.5 meter spacing per tree requires $1,500 \mathrm{~kg}$ of seeds (1,500 Porang).

Basically, this porang seed problem is very unique. The porang seeds to be purchased are basically one-time purchases. This means that farmers who successfully plant do not have to worry anymore about the high price of seeds because they will be able to produce and even sell porang seeds. Every porang that is successfully planted, during the harvest season will also produce a lot of seeds on each stalk that falls to the ground. This phenoma which is sometimes also responded positively by being determined to buy seeds at any price, considering that after harvesting to replant they do not need to buy seeds. All of this general picture, becomes a real condition experienced by farmers and prospective farmers in Bulu Village, Pilang Kenceng District, Madiun Regency, East Java Province - Indonesia.

\section{The learning process of the porang farmer group as adult learners.}

Learning activities of farmer group members take place informally (discussion) and practice-based among farmers as learners. The implementation of learning activities for farmer group members has no time limit, but whenever they make an appointment (via Whatsapp Group) or meet on the land that is supposed to be planted with porang, at that time learning activities in the form of interaction among farmers take place. Learning sources apart from relying on the internet (Youtube), fellow farmers who have prior / experience are the main source of learning. The learning media used are aside from the farmers' own smartphones, as well as fellow farmers and the porang itself, starting from seeds, soil, hoe, fertilizer, water, porang stems that have grown and porang crops. The whole stages of the porang farmer group learning process as far as field discoveries are as follows:

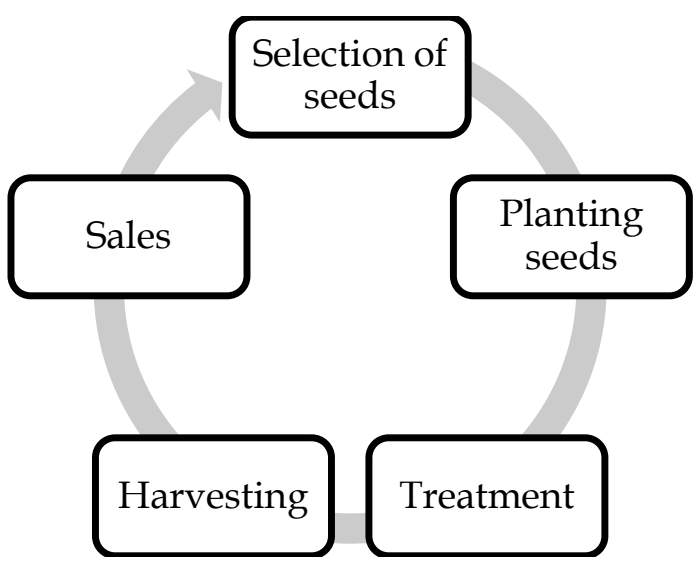

Figure 3. Operational discussion material by Porang farmer group

Selection of seeds, the technique of selecting porang seeds according to Mr Kholiq (59), is the most important stage at the beginning of planting porang;

"...A good porang cannot be separated from the accuracy of selecting the right seed. There are two kinds of porang seeds, namely; Frog seeds (porang seeds) and porang that have grown are packed in polybags. Frogs are the most appropriate porang seeds apart from being more economical in terms of price, as far as our experience has a better harvest weight compared to porang seeds in polybags. " 
Planting seeds, planting porang seeds is best planted during the rainy season, which is around November - December. Mr. Adi (52), as a member of the farmer group who succeeded in carrying out planting for the second time explained;

"I can show you how to plant the right seeds, so they can grow well. The selected porang seeds are inserted one by one into the planting hole with the location of the bud facing upwards, for each planting hole filled with 1 porang seed with a spacing of $1 \mathrm{~m} \times 1 \mathrm{~m}$. Cover the planting hole with $3 \mathrm{~cm}$ thick soil".

Treatment, a porang farmer needs to understand the stages in porang care from the first time it is planted to harvested and even sold. Some literature sources say that basically porang plants do not need complicated maintenance, unless if you expect a good duration and yield, treatment can be an alternative strategy. Mr. Sabar (50), as a member of the farmer group during a discussion with other farmer members said;

"....There are several stages that we need to go through for good porang care. After the plants are transplanted into the planting area, you must fertilize them regularly. This is intended for optimal growth and development, so that they can get abundant harvests. Sprinkle 5 grams of GDM SaMe Granule Bio Organic evenly into the planting hole 14 days before planting. Mix 1 glass of GDM Black BOS mineral water into a spray tank filled with water. Then spray it all over the surface of the planting hole that is wet and damp. Do it until it meets the dose of $5 \mathrm{~kg} / \mathrm{ha}$. On planting day (0 HSS), fertilize using GDM's Specialist Food Crops Organic Fertilizer. Dissolve $500 \mathrm{ml}$ of GDM's Specialist Food Crops Organic Fertilizer in a spray tank filled with water. Stir until homogeneous. Spray a solution of GDM Specialist Food Crops Organic Fertilizer to all parts of the plant.

Harvesting, porang as an agricultural commodity can be harvested for the first time after it reaches 2-3 years (depending on soil conditions and the porang plant itself). The harvested porang is the large porang weighing more than $3 \mathrm{~kg} /$ porang, while the small tubers are left to be harvested the following year. Mr. Andika (48), as a member of a farmer group who has successfully harvested porang, explained the following discussion to members of the farmer group;

"...The characteristics of porang that are ready for harvest are when the leaves have dried (turned yellow / brown) and fell to the ground. One porang tree can produce about $3 \mathrm{~kg}$ of tubers and from about 40 thousand plants in one hectare can be harvested 80 tons of tubers in the second year period. After the tubers are harvested, then they are cleaned from the soil and roots. The tubers are then cut and then dried in the sun, cutting the tubers must be correct because it determines the quality of the porang produced."

Sales, porang sales techniques are very easy. This is because the need for porang as raw material for cosmetic tools and most importantly food in China, South Korea and Japan is increasing. The existence of porang exporters is also increasing, which means that a porang farmer can easily sell his crops to the exporters who have the highest price. Sumarno (54), as a member of a farmer group who has succeeded in selling his crops several times, shared his experiences in a discussion with other members of the porang farmer group;

"..Friends, members of the Porang farmer group, please do not feel concerned about where to sell all of your friends' crops. The existence of porang factories around our area, and the collectors / exporters of porang at any time will be pleased to come to pick up our crops."

\section{Adult learning practices in the Porang farmer group}

The dominant learning strategy used by farmers as adult learners is discussion. This discussion activity involves all members of the farmer group with uncertain or flexible time. One of the interesting topics for discussion was about porang planting reviews from planting to harvest including market prices. When examined in depth, this topic is a construction of learning materials used by members of the Porang farmer group as adult learners in learning Porang farming techniques. Mr. Suparno (56), as a member of the farmer group explained;

"...discussion becomes important for us, because we really learn and get actual information and knowledge about why, what and how to cultivate porang from start to finish (sales). We feel more enthusiastic about learning and make the right decisions during planting practice when we get this information."

The members of the porang farmer group are basically farmers with various formal education graduates. Their last education is generally Elementary, Primary school (ES) and Junior High School (JHS) level. In addition, members of farmer groups also have varying levels of welfare and social status. Mr. Suparman (45), as a member of the Porang farmer group stated;

"...All of our friends who are members of this porang farmer group, basically come from various family backgrounds. There are some rich families with a large area of porang agricultural land, but there 
are also some who come from poor families with a small area of land. Discussion interactions that generate a lot of knowledge regarding the progress of planting porang would not be possible without mutual respect and respect among our fellow members of our porang group with of course different life backgrounds."

Activities in the form of discussions carried out by the Porang farmer groups were seen to be more effective with the exchange of opinions and experiences. Mr. Kholig (59), as a member of the farmer group, confirmed this;

"...We always use topics or materials that are relevant to the needs of knowledge at that time in every discussion. The knowledge from more experienced members is then collaborated with the experiences of other farmer group members. Thus, we feel that the results of the discussion for the common interest also come from contributions from the experiences and thoughts of friends."

The agreement during the discussion usually takes place in the whatsapp group owned by the porang farmer group. This step makes members better prepare materials and questions for discussion. Sukadi (43), a member of the Porang farmer group explained;

"...the participation of friends in the discussion was extraordinary. This can be seen from the number of attendance as a form of learning readiness for our Porang farmer group members above ninety percent. This condition is due to the deliberation and consensus pattern that we agreed on in terms of time and discussion material through Whatsapp Group."

The members of the porang farmer group generally own land planted with porang. Thus, the discussion materials they use focus on the problems they are facing while farming. Mr. Kasdu (52), a member of the Porang farmer group explained;

"...I felt that before the discussion, friends had prepared material and questions to be discussed as discussion material. It can be seen from the materials and questions used in the discussion by the members of the Porang farmer group, I also experienced it".

The age of the farmer group members, who are adults and tend to be old, make the learning process unable to be absorbed quickly with just one discussion and practice. This condition is certainly different when compared to the learning process by children. Mr. Suwito (54), as the head of the farmer group explained;

"...the knowledge that we get from discussion material with friends, even though we have practiced it in our agricultural area, but we need to discuss it or study it again independently. This is important, apart from confessing that our young friends forgot about the discussion material, we also want to strengthen our belief in the discussion materials, knowledge and experiences shared by fellow farmer group members."

The fear of failure from a porang farming practice is sometimes the biggest obstacle in the learning process of members of the porang farmer group. Mr. Adi (52), as a member of the farmer group explained;

"...outside the discussion about talking about porang, our fellowman once told me that he felt doubt in planting porang. Apart from being a new commodity, in the agricultural context, it is still commonplace for us to implement in our agricultural area which was previously used for local and general agricultural commodities such as maize, sugar cane and secondary crops. The developments, demands and needs of the times that are increasingly changing seem to be futile from our doubts. What we feel right now is that belief after belief grows at the same time the intensity of the discussion is getting higher."

Farmers in the context of learning as adult learners require a different approach from children's approaches. Adults have a lot of experience that can be a very good basis for further learning. They value new learning that builds on what they already know or that helps them solve current problems they face. The experiential learning cycle (below) helps people to move beyond simple 'trial and error' by using all the steps in the cycle. Each time they try a new way after their 'big picture' thinking, they are moving forward as a learner. This becomes a cycle of active learning (Barbara Pamphilon, 2017). The cycle below is an adaptation of the work of David Kolb; 


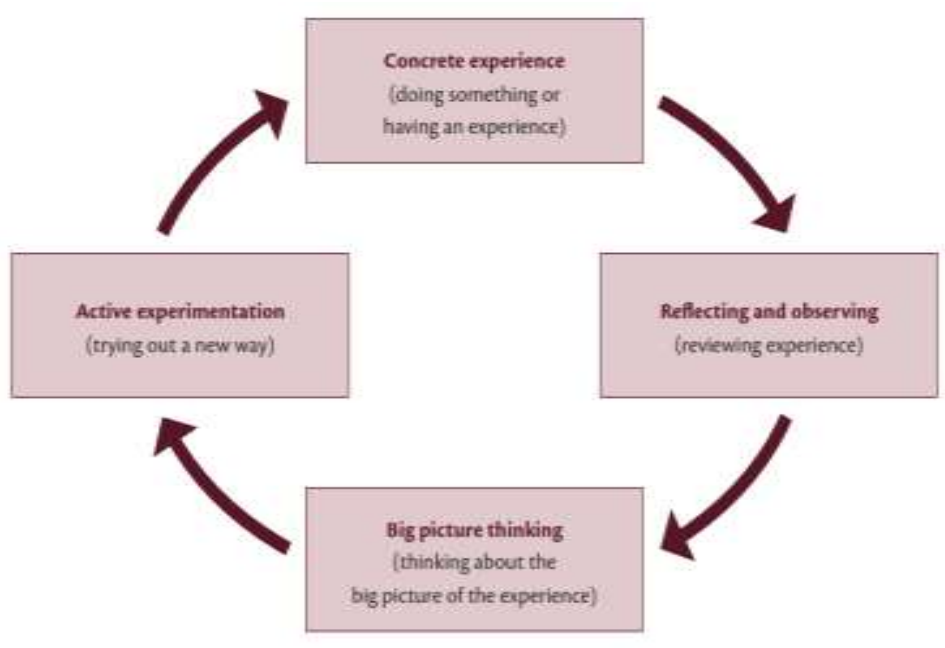

Figure 4. The cycle below is an adaptation of the work

Source: Kolb D.A. 1984. Experiential learning: experience as the source of learning and development (volume 1). Prentice-Hall: Englewood Cliffs, NJ.

Based on The cycle below is an adaptation of the work of David Kolb, visible adult learning process shows and requires a special approach. Andragogy as an adult learning approach, is very relevant and appropriate to be applied in the learning concept of porang farmers, who as a whole are adults.

Knowles (1980) defined andragogy as the "art and science of helping adults learn" (p. 43). Andragogy is based upon six essential hypotheses concerning the attributes of adult learners (Knowles, Swanson, \& Holton, 2005). Knowles et al. reported that educators' understanding of the six hypotheses in andragogy will assist them in organizing and creating successful instruction for adult learners. The implementation of the six principles of andragogy is very popularly used in various learning activities that involve adults. Berdasarkan Gambar 2.2 Andragogy in practice (Knowles, Holton, and Swanson, 1998), graphically shows that andragogy is a core set of adult learning principles. The six principles of andragogy are (1) The learner's need to know, (2) Self-Concept of the learner, (3) Prior experience of the learner, (4) Readiness to learn, (5) Orientation to learning, and (6) Motivation to learn. In the context of learning the porang farmer group, these principles are developed naturally. This condition is very reasonable due to the latest formal education and culture in the Porang farmer group in Bulu Village, Pilangkenceng District, Madiun Regency.

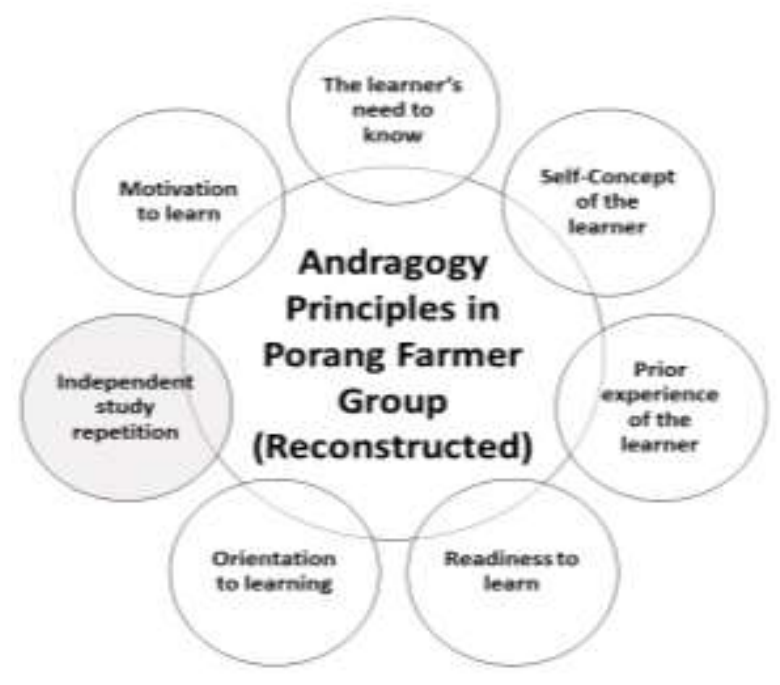

Figure 5. Porang farmer learning principles as adult learners

The learner's need to know, Adults want to know why they need to learn something before undertaking learning (Knowles et al., 2005). Facilitators must help adults become aware of their "need to know" and make a case for the value of learning (Carrie Ota, 2006). In the context of members of the porang farmer group as adult learners, in each discussion, each member has various experiences with 
each other and exchanges both positive and negative experiences. The process of exchanging experiences indirectly makes other members aware of the importance of continuously learning to explore porang cultivation from beginning to end, namely the sale of the harvest.

Self-Concept of the learner, Adults believe they are responsible for their lives (Knowles et al., 2005). They need to be seen and treated as capable and self-directed. Facilitators should create environments where adults develop their latent self-directed learning skills (Brookfield, 1986). Discussions as a learning model for farmer group members take place naturally (Without any special learning planning instruments). The culture of mutual respect and respect as fellow Javanese as the original tribe of the farmers, has an impact on mutual openness and help among fellow farmers as adult learners. This condition adds to a harmonious atmosphere in the discussion process so that learning outcomes can be easily and effectively achieved.

Prior experience of the learner, Adults come into an educational activity with different experiences than do youth (Knowles et al., 2005; Merriam \& Caffarella, 1999). There are individual differences in background, learning style, motivation, needs, interests, and goals, creating a greater need for individualization of teaching and learning strategies (Brookfield, 1986; Silberman \& Auerbach, 1998). The richest resource for learning resides in adults themselves; therefore, tapping into their experiences through experiential techniques (discussions, simulations, problem-solving activities, or case methods) is beneficial (Brookfield, 1986; Knowles et al., 2005; McKeachie, 2002; Silberman \& Auerbach, 1998). The core material of the discussion carried out is related to experiences or problems related to Porang farming. However, the discussion is interesting and rich, when they elaborate on their experiences as farmers so far with the actual problems being faced, namely related to porang farming.

Readiness to learn, Adults become ready to learn things they need to know and do in order to cope effectively with real-life situations (Knowles et al., 2005). Adults want to learn what they can apply in the present, making training focused on the future or that does not relate to their current situations, less effective (Carrie Ota, 2006). Porang, with its potential, is the main reason for the readiness shown by the members of the Porang farmer group. The level of participation in every moment of discussion and the availability of learning resources (seeds, fertilizers and agricultural land) that they have is a form of seriousness in studying people as new agricultural commodities for them.

Orientation to learning, Adults are life-centered (task-centered, problem-centered) in their orientation to learning (Knowles et al., 2005). They want to learn what will help them perform tasks or deal with problems they confront in everyday situations and those presented in the context of application to real-life (Knowles et al., 2005; Merriam \& Caffarella, 1999). The implementation of the discussion as a form of learning model for the members of the porang farmer group as adult learners, although in substance they have plans that they are not aware of it is intentional. The results of musyarawah and consensus in the whatsapp group they have do not only discuss the time agenda, but also materials related to the agricultural problems they are facing. Thus, of course, learning orientation in the form of discussions carried out is always centered on their real problems.

Independent study repetition, Porang farmers as adult learners and in reality approaching old age, have a memory in remembering which is certainly no better than adolescence. With full awareness, they impose themselves in the form of assignments or self-practice in their homes or fields related to material or knowledge prior to learning through discussion. They took this effort to repeat the material from the discussion that previously did not understand or already understood, because of their age which is easy to forget. Neuroimaging studies have revealed that repetition of a specific cognitive task can change the excitability of distinct brain regions (Olesen, Westerberg, \& Klingberg, 2004; Thompson, Waskom, \& Gabrieli, 2016; Westerberg \& Klingberg, 2007). Selain itu, The repetition of a cognitive task promoted motor learning in the early phase. We show that cognitive tasks have the potential for a progress-dependent promotion of motor learning. The progress of the better skills shown by the members of the porang farmer group even though they are experienced farmers in their background, the repetition of learning techniques in the form of assignments or self-training in their respective homes or fields, has a big contribution in the effort to become porang farmers who are professional.

Motivation to learn, Adults are responsive to some external motivators (e.g., better job, higher salaries), but the most potent motivators are internal (e.g., desire for increased job satisfaction, selfesteem). Their motivation can be blocked by training and education that ignores adult learning principles (Knowles et al., 2005). The potential of porang as an export agricultural commodity with a high selling value, replacing traditional local agricultural commodities such as maize, sugar cane and crops with low selling value. This phenoma is one of the external motivations that members of farmer groups experience before turning to become porang farmers. In addition, the condition of welfare as a farmer which got worse in the Covid-19 pandemic season was an internal motivation that shaped his determination and enthusiasm to continue to learn to cultivate porang as an export agricultural commodity with a high 
selling value that was able to improve the standard of life of members of the Porang farmer group and their families.

\section{CONCLUSION}

The discussion is a learning model that occurs and is effectively used by members of the Porang farmer group in Bulu Village, Pilang Kenceng District, Madiun Regency, East Java Province - Indonesia. The members of the Porang farmer group as adult learners naturally reconstruct the andragogical principles commonly used in adult learning practice into the following forms; (1) dult learners have a learning orientation that is relevant to the problem, (2) have a more mature and diverse concept and readiness for learning, (2) have knowledge and experience as teaching and learning capital, (3) have internal motivation and need external motivation, (4) need respect and appreciation in learning, (5) need a representative learning situation, (6) safe and comfortable. (7) Adult learners will also be more effective and optimal in their learning if there is certainty of learning outcomes. The certainty of learning outcomes by porang farmers as adult learners is a new finding in an andragogy principle. Porang farmers as adult learners in this study will increase all the learning resources they have, there is no doubt about the benefits of the learning they are doing or will do.

\section{ACKNOWLEDGEMENTS}

The author would like to say thank you to the rector of Universitas Negeri Surabaya who has given permission and support to study at the post-graduate program in Universitas Negeri Malang. The corresponding author would like to thank the second, third, and fourth authors for the discussions and various viewpoints.

\section{REFERENCES}

Alonso-Sande, M., Teijeiro-Osorio, D., Remuñán-López, C., \& Alonso, M. J. (2009). Glucomannan, a promising polysaccharide for biopharmaceutical purposes. European Journal of Pharmaceutics and Biopharmaceutics, 72(2), 453-462.

Altbach, P. G., Reisberg, L., \& Rumbley, L. E. (2010). Trends in global higher education: Tracking an academic revolution. Paris, France: UNESCO. Retrieved: June 10, 2020, https://unesdoc.unesco.org/ark:/48223/pf0000183168_eng

Bear, Anne A. Ghost. 2012. Technology, Learning, and Individual Differences. Journal of Adult Education, 41(2), 27-42.

Beckner, C., Blythe, R., Bybee, J., Christiansen, M. H., Croft, W., Ellis, N. C., \& Schoenemann, T. (2009). Language is a complex adaptive system: Position paper. Language Learning, 59, 1-26.

Boyd, R. D. \& Apps, J. W. 1980. A Comcept Model for Adult Education. San Francisco: Jossey-Bass.

Brookfield, S. D. (1986). Understanding and facilitating adult learning: A comprehensive analysis of principles and effective practices. California: Jossey-Bass, Inc.

Caruth, G. D. (2013). Toward a Definition of Andragogy: A Grounded Theory Approach International. Journal of Advanced Research, 1(9), 600-607.

Charness, N., \& Boot, W. R. (2009). Aging and information technology use potential and barriers. Current Directions in Psychological Science, 18(5), 253-258.

Coget, J. F. (2011). Technophobe vs. techno-enthusiast: Does the Internet help or hinder the balance between work and home life? The Academy of Management Perspectives, 25(1), 95-96.

Corbin, J., \& Strauss, A. (2015). Basics of Qualitative Research. Thousand Oaks, CA: Sage.

Creswell, J. W. (2007). Research design: Qualitative, quantitative, and mixed methods approaches (2nd ed). Thousand Oaks, CA: SAGE Publications, Inc.

Creswell, J.W. (2013). Qualitative inquiry \& research design: choosing among the five approaches. Thousand Oaks, CA: SAGE Publications, Inc.

Da Silva Barreto, M., Garcia-Vivar, C., \& Silva Marcon, S. (2018). Methodological quality of Grounded Theory research with families living with chronic illness. International journal of Africa nursing sciences 8, 14-22.

Dearing, J. W. (2009). Applying Diffusion of Innovation Theory to Intervention Development. Research on Social Work Practice, 19(5), 503-518.

Dorrian, J., \& Wache, D. (2009). Introduction of an online approach to flexible learning for on-campus and distance education students: Lessons learned and ways forward. Nurse Education Today, 29(2), 157-167. 
Dyer, Christopher (2007). "A Suffolk Farmer in The Fifteenth Century". Agricultural History Review. 55 (1): $1-22$.

Everett M, Rogers (2003). Diffusion of Innovation. 5th. Edition. New York: The Free Pass A Division of Macmillan Publishing Co, Inc.

Glasser, W. (1998). Choice theory: A new psychology of personal freedom. New York: Harper Collins.

Harmayani, E., Aprilia, V., \& Marsono, Y. (2014). Characterization of glucomannan from Amorphophallus oncophyllus and its prebiotic activity in vivo. Carbohydrate Polymers, 112, 475-479.

Hintzman, D. L. (1976). Repetition and Memory. Psychology of Learning and Motivation, 47-91.

Holton, E. F., Swanson, R. A., \& Naquin, S. S. (2008). Andragogy in Practice: Clarifying the Andragogical Model of Adult Learning. Performance Improvement.

Kimura, T., \& Nakano, W. (2019). Repetition of a cognitive task promotes motor learning. Human Movement Science, 66, 109-116.

Knowles, M. S. (1980). The Modern Practice of Adult Education from Pedagogy to Andragogy. Cambridge: Englewood Cliffs Prentice Hall.

Knowles, M. S., Swanson, R. A., \& Holton, E. F. III (2005). The adult learner: The definitive classic in adult education and human resource development (6th ed.). California: Elsevier Science and Technology Books.

Knowles, M., Holton III, E., \& Swanson, R. (1998). The Adult Learner The Definitive Classic in Adult Education and Human Resource Development. San Diego, CA: Elsevier.

Knowless, M. S. (1975). Self-Directed Learning: A Guide for Learners and Teachers. New York: Association Press.

Kolb, D.A. (1984). Experiential learning: experience as the source of learning and development. Englewood Cliffs, NJ: Prentice Hall.

McEntee, M. 2013. Beyond linear technology transfer: Examining learning environments in six sustainable agriculture participatory research projects. Extension Farming Systems Journal, 9(1), 114.

McKeachie, W. J. (2002). MeKeachie's teaching tips: Strategies, research, and theory for college and university teachers (11th ed.). Massachusetts: Houghton Mifflin Company.

Merriam, S. B., \& Caffarella, R. S. (1999). Learning in adulthood: A comprehensive guide (2nd ed.). California: John Wiley \& Sons, Inc.

Musyafak A, Ibrahim TM. 2005. Strategi Percepatan Adopsi dan Difusi Inovasi Pertanian Mendukung Prima Tani. Analisis Kebijakan Pertanian. 3(1). 20-37.

Olesen, P. J., Westerberg, H., \& Klingberg, T. (2004). Increased prefrontal and parietal activity after training of working memory. Nature Neuroscience, 7, 75-79.

Ota, C., DiCarlo, C. F., Burts, D. C., Laird, R., \& Gioe, C. (2006). Training and the needs of adult learners. Journal of Extension, 44(6).

Pamphilon, Barbara. (2017). The Farmer-to-Farmer Adult Learning Manual: A Process and Resources for the Development of Farmers as Peer Educators. Canberra: Australian Centre for International $\begin{array}{lllll}\text { Agricultural } & \text { Research } & \text { (ACIAR). }\end{array}$ https://www.canberra.edu.au/research/faculty-research-centres/csc/family-farm-teamsprogram/publications

Puspitorini Pipit, S., Putra Andhika, C., \& Ernes Admiral. (2019). Pemberdayaan Masyarakat Jembul dengan Teknologi Tepat Guna Pengolahan Chips Porang dalam meningkatkan Daya Saing. International Journal of Community Service Learning, 3(4), 244-251.

Reischmann, J. (2004). Andragogy: History, meaning, context, function. Retrieved June: 13, 2020 http://www.andragogy.net.

Rogers, Everett M. (1983). Diffutions of innovations. 3rd Edition. New York: The Free Pass A Division of Macmillan Publishing Co, Inc.

Silberman, M. L., \& Auerbach, C. (1998). Active training: A handbook of techniques, designs, case examples, and tips (2nd ed.). California: John Wiley \& Sons, Inc.

Simamora, B. 2003. Membongkar Kotak Hitam Konsumen. Jakarta: Gramedia Pustaka Utama.

Starks, H., \& Trinidad, S. B. (2007). Choose your method: A comparison of phenomenology, discourse analysis, and grounded theory. Qualitative Health Research, 17(10), 1372- 1380.

Strauss, A. \& Corbin, J. (1990). Basics of Qualitative Research: Grounded Theory Procedures and Techniques. Newbury Park, CA: Sage Publications.

Strauss A, Corbin J. 2008. Pesquisa qualitativa: técnicas e procedimentos para o desenvolvimento de teoria fundamentada. $2^{\mathrm{a}}$ ed. Porto Alegre: Artmed.

Suanmali, C. (1981). The core concepts of andragogy. (Unpublished doctoral dissertation) Ann Arbor: Dissertation Abstracts International. (UMI No. 8207343). 
Tester, R. F., \& Al-Ghazzewi, F. H. (2013). Mannans and health, with a special focus on glucomannans. Food Research International, 50(1), 384-391.

Thompson, T. W., Waskom, M. L., \& Gabrieli, J. D. (2016). Intensive working memory training produces functional changes in large-scale frontoparietal networks. Journal of Cognitive Neuroscience, 28, $575-588$.

Westerberg, H., \& Klingberg, T. (2007). Changes in cortical activity after training of working memory-a single-subject analysis. Physiology and Behavior, 92, 186-192.

Yanuriati, A., Marseno, D. W., Rochmadi, \& Harmayani, E. (2017). Characteristics of glucomannan isolated from fresh tuber of Porang (Amorphophallus muelleri Blume). Carbohydrate Polymers, 156, 56-63.

Young, K. S., \& Rogers, R. C. (1998). Internet Addiction: Personality Traits Associated with Its Development. Retrieved June 20, 2020 www.netaddiction.com/articles/personality_correlates.pdf.

Yue, Zuohua. 2009. On Definition of Farmers and Its Connotation \& Particularity in Modern Agricultural Background. Asian Social Science, 5(2), 19-23.

Zhang, C., Chen, J., \& Yang, F. (2014). Konjac glucomannan, a promising polysaccharide for OCDDS. Carbohydrate Polymers, 104(1), 175-181.

Zhang, Y. Q., Xie, B. J., \& Gan, X. 2005. Advance in the applications of konjac glucomannan and its derivatives. Carbohydrate Polymers, 60(1), 27-31. 